\title{
Comparative Study on Two Types of Nonpillar Mining Techniques by Roof Cutting and by Filling Artificial Materials
}

\author{
Enze Zhen, ${ }^{1,2}$ Yubing Gao ${ }^{(D,},{ }^{1,2}$ Yajun Wang, ${ }^{3}$ and Siming Wang ${ }^{1}$ \\ ${ }^{1}$ State Key Laboratory for Geomechanics and Deep Underground Engineering, China University of Mining \& Technology, \\ Beijing 100083, China \\ ${ }^{2}$ School of Mechanics and Civil Engineering, China University of Mining \& Technology, Beijing 100083, China \\ ${ }^{3}$ Department of Geotechnical Engineering, College of Civil Engineering, Tongji University, Shanghai 200092, China
}

Correspondence should be addressed to Yubing Gao; yubing.gao@yahoo.com

Received 19 March 2019; Accepted 18 June 2019; Published 1 July 2019

Academic Editor: Venu G. M. Annamdas

Copyright (C) 2019 Enze Zhen et al. This is an open access article distributed under the Creative Commons Attribution License, which permits unrestricted use, distribution, and reproduction in any medium, provided the original work is properly cited.

\begin{abstract}
Gob-side entry retaining is an environmentally friendly nonpillar mining technology with high efficiency and safety. With the continuous exploration of the gob-side entry retained by filling (GERF) with roadside supports, the GERF has enabled nonpillar mining. However, dense roadside supports or filled artificial pillars become subject to the pressure of roof pressure instead of coal pillars, which causes problems. Recently, an original innovative gob-side entry retaining technology by roof cutting and pressure relief (RCPR) was developed and extensively implemented in China's coal production. The gob-side entry formed by different retaining methods has exhibited some differences in the strata behaviors and the results of retained roadways. Via industrial case and numerical simulation, this study explored the influence of entry retaining methods on the results of the entry retained. The results indicate that the total deformation of the surrounding rock of the GERF is larger and more severe; the convergence between the roof and floor and the entry sides displacement is $885 \mathrm{~mm}$ and $216 \mathrm{~mm}$, respectively; the hydraulic support pressure near the retained entry is larger; and the peak value is $38.7 \mathrm{MPa}$. The deformation of the surrounding rock by RCPR is relatively small; the convergence between the roof and the floor and the entry sides displacement is $351 \mathrm{~mm}$ and $166 \mathrm{~mm}$, respectively; the hydraulic support pressure near the retained entry is weakened to a certain extent; the peak value is $32.2 \mathrm{MPa}$; and the peak pressure is reduced by $16.8 \%$ compared with the GERF. A numerical simulation analysis reveals the following findings: RCPR changes the surrounding rock structure of a gob-side entry, optimizes the surrounding rock stress environment, and belongs to active pressure-relief entry retaining; the GERF does not adjust the surrounding rock structure of a gob-side entry and belongs to passive pressure-resistance entry retaining; and the surrounding rock of a gob-side entry is significantly affected by pressure. These two methods of gob-side entry retaining have different effects on the surrounding rock of the entry retained. This study can contribute to an exploration of the strata behaviors and the results of a retained roadway by the GERF or RCPR method.
\end{abstract}

\section{Introduction}

Long-wall mining is currently the main mining method of coal output in China $[1,2]$. In traditional long-wall mining, a coal pillar is required and two mining roadways need to be excavated while mining coal. The installation of coal pillars not only wastes resources but also causes stress concentration in the area of the coal pillars, which causes mine disasters [3]. Therefore, to cancel the arrangement of coal pillars, realize continuous mining without coal pillars, optimize the layout of exploitation, and eliminate stress concentration in the upper and lower areas of coal pillars, gobside entry retaining has extensively been employed in the
UK, Germany, Poland, Russia, and China as a means for nonpillar mining since the 1950s. In the mining process supports with dense pillars, timber cribs or gob-side filling along the gob edges [4-6] is erected on the current mining face and a roadway is retained in the previous panel to make it available for the adjacent mining face, achieve the ends of canceling panel coal pillars, and reduce the roadway tunneling ratio.

The gob-side entry retained by filling (GERF) with roadside supports has enabled nonpillar mining over past five decades of development. Nevertheless, problems such as significant stress on the supporting structure, stress concentration of the filling body, and strong strata behaviors 
persist [7]. In 2009, Chinese scholars proposed gob-side entry retaining by roof cutting and pressure relief (RCPR) $[8,9]$ to eliminate the use of artificial fillers, which reduces the cost of gob-side entry retaining to some extent. In addition, roof cutting can be used to improve the roof structure and its stress environment, which weakens the stress of the surrounding rock to some extent, which would be more beneficial to stabilizing the gob-side entry retaining.

Strata behavior is the root cause of the surrounding rock deformation of gob-side entry during mining activities. Thus, the deformation guidelines of the gob-side surrounding rock in the mining process are believed to be a key point that one must grasp. In recent years, experts and scholars have conducted a substantial amount of research on the stability and deformation law of the surrounding rock of a gob-side entry [10-17]. To grasp the large deformation mechanism of roadway driving along the goaf under unstable overlying rock strata, Zhang [10] adopted a digital panoramic borehole camera system to observe the roof rock strata of the roadway driving along the goaf and investigated the fractures distribution and the evolution law was investigated. By mechanical analysis and laboratory experiments, Zhang [11] explored the surrounding rock characteristics of gob-side roadways with or without coal pillars and discussed the movement of the main roof, which has large impact on the stability of the surrounding rock of a gob-side roadway. Kan [12] analyzed the movement rule of overlying strata on secondary gob-side entry retaining, while also introducing and analyzing the concept of a support structure. Based on the movement laws of overlying strata in traditional gob-side entry retaining technology, $\mathrm{He}$ [13] investigated the mechanism of pressure relief of a gob-side roof. Xie [14] explored the principal stress difference and plastic zone in the process of buried depth from $550 \mathrm{~m}$ to $1250 \mathrm{~m}$ with the aid of a simulation software to solve the surrounding rock control problems in kilometer depth gobside entry driving. Wu [15] clarified the mechanism of asymmetric deformation and failure in surrounding rock to solve the problem of asymmetric deformation and its control in deep gob-side entry retaining. Wang et al. [16] put forward a major coal mining innovation method of selfforming roadway without coal pillar in long-wall mining with the core technology of "directional roof cutting with the support using a constant resistance large deformation anchor cable" and carried out field engineering application successfully. Based on the breaking off characteristics of overlying rock, $\mathrm{Li}$ [17] built the mechanical models of large and small structures and analyzed the formation conditions of low and high arches.

This research shows that the stability state and deformation laws of surrounding rock of a gob-side entry retained by the GERF or the RCPR for different geological conditions have fully been mastered. However, a comparative analysis of the strata behaviors has not been performed for a retained entry of gob-side entry formed by two retained methods in the same geological condition. This study was conducted with the engineering background of the test retaining entry. A comparative analysis for existing GERF and RCPR entry retaining methods was performed via numerical simulation and field mine pressure measurements to reveal the similarities and differences of different entry retaining methods with respect to the strata behaviors due to retained entry. The research findings are expected to provide a reference for the application of different entry retaining techniques.

\section{Nonpillar Mining by Filling Materials (NMFMs) and Nonpillar Mining by Roof Cutting (NMRC)}

2.1. Existing Nonpillar Mining Methods. To solve the issues of the traditional pillar mining method, such as resource waste, stress concentration, and ignition of residual pillar, the nonpillar mining method has extensively been applied. This method can not only improve the coal recovery rate but also decrease the development ratio and eliminate various potential hazards caused by coal pillars [18-20].

Currently, gob-side entry retaining is the main method to achieve nonpillar mining. When using this method in coal mining on a mining face, only a gate entry needs to be driven, an entry protection pillar is not needed. In the mining process on a current mining face, supports with godside filling should be erected along the gob edges and the entry in the previous panel should be retained. The NMFM method was employed for the adjacent mining face; the entry layout is shown in Figure 1(a). Compared with traditional pillar mining methods, this technique reduces the excavation of gate entries by $50 \%$ and cancels the setup of panel coal pillars, which has distinct advantages in terms of conserving coal resources, reducing mining costs, and relieving the tension of mining and tunneling continuance.

Nonpillar mining by roof cutting (NMRC) was initially proposed in 2009 [21, 22]; its first test trial was successfully implemented in the same year in the Baijiao Coal Mine in Sichuan. In contrast with previous NMFM, NMRC forms a sidewall with the roof rock without the need for filling concrete. The active roof cutting and pressure relief eliminates the use of roadside filling. The entry layout of NMRC is shown in Figure 1(b).

\subsection{Gob-Side Entry Retained by Filling (GERF) with Roadside} Supports. To weaken the influence of ground pressure on mining roadway in the long-wall mining process, coal pillars are usually retained along the goaf [23]. Gob-side entry retained by filling (GERF) with roadside supports refers to erecting a side of roadway by filling artificial backfill, blocking the goaf gangue, and resisting the subsidence of the retained entry roof in the mining process on the current mining face. An entry in which one side having an artificial wall and the other side having integrated coal can then be formed, as shown in Figure 2. The GERF cancels the roadway excavation and replaces the reserved coal pillar with the artificial filling body. This can help improve the coal recovery rate and is an important technical support means for nonpillar mining.

2.3. Gob-Side Entry Retained by Roof Cutting and Pressure Relief $(R C P R)$. The technology of gob-side entry retained by roof cutting and pressure relief is to reinforce the entry roof 


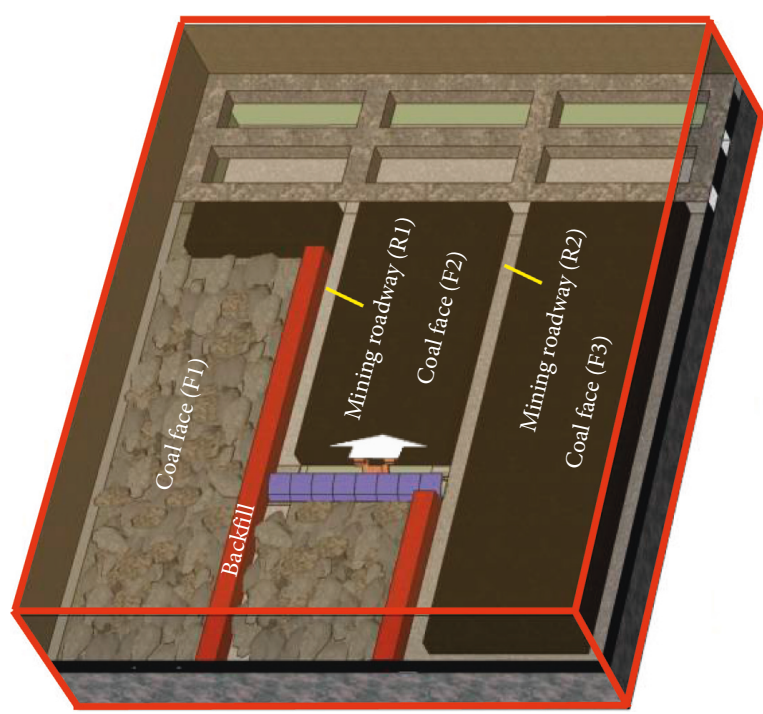

(a)

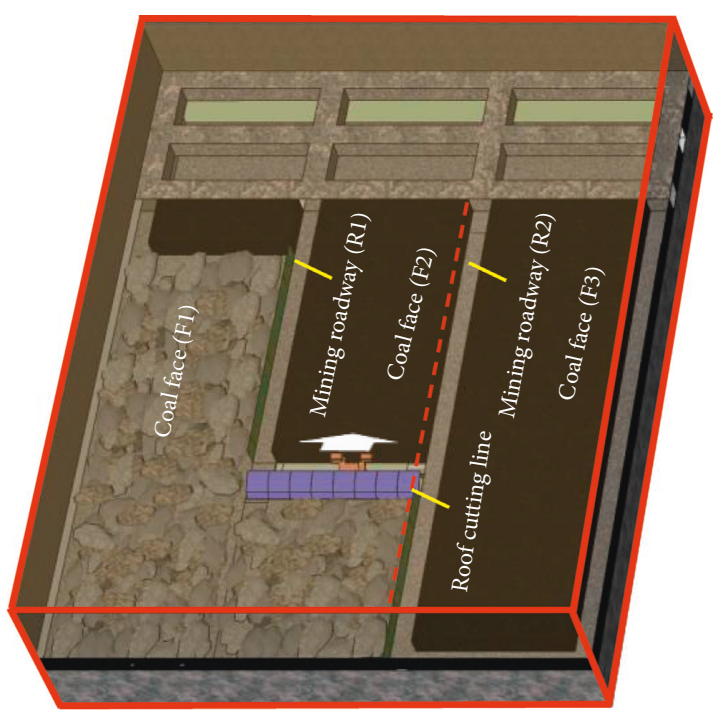

(b)

FIGURE 1: Entry layout of nonpillar mining. (a) NMFM method; (b) NMRC method.

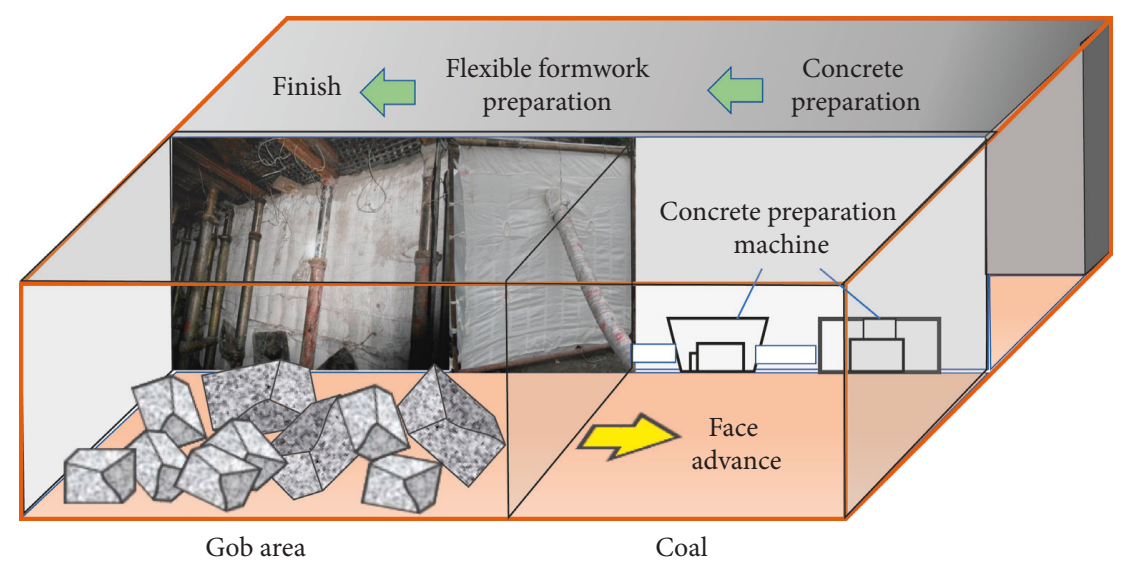

Figure 2: Principle of gob-side entry retained by filling with roadside supports.

with a constant resistance and large deformation anchor (CRLDA) cable and conduct an evaluation of the precrack on the retaining entry roof before mining. The function of the roof cutting is to cut off the transmission path of ground pressure on the roof of the goaf. The periodic weighting action of the roof is used to promote the roof fall along the precracked face. The retained entry on one side was rock, and the retained entry on the other side was integrated coal, as shown in Figure 3. Compared with the gob-side entry retained by filling, this method cancels the layout of an artificial filling body, realizes the self-construction of a retained entry by utilizing the ground pressure and some roof rocks, and reduces the cost of a gob-side retaining roadway.

\section{Methodology}

3.1. Field Experiment. The field test site is located at the 011810 working face of the Jinfeng Coal Mine in Wuzhong City, Ningxia, China. The total length of the 011810 head entry is $1023 \mathrm{~m}$, and the mining length of the 011810 working face is $780 \mathrm{~m}$. To analyze the effect of different retaining methods in the same geological condition, $550 \mathrm{~m}$ of the head entry is selected to adopt entry retaining by RCPR, and $230 \mathrm{~m}$ is selected to adopt the GERF method, as shown in Figure 4.

First, the roof of the gob-side entry retaining by RCPC is strengthened by using a constant resistance anchor cable. The roof of the gob-side entry retaining by GERF is strengthened by using an ordinary anchor cable in the process of the field test. After the roof of entry is strengthened, directional blasting at the roof was conducted along the gob side by RCPC. For the section of gob-side entry retaining by GERF, a ground test is conducted to determine the ratio of filling materials and flexible formwork. For the face mining, two methods of entry retaining are applied in different sections to achieve the goals.

\subsection{Numerical Simulation}

3.2.1. Finite-Difference Modelling Software FLAC3D. FLAC3D is a prevalent simulation software in engineering, including civil engineering, mining engineering, and 


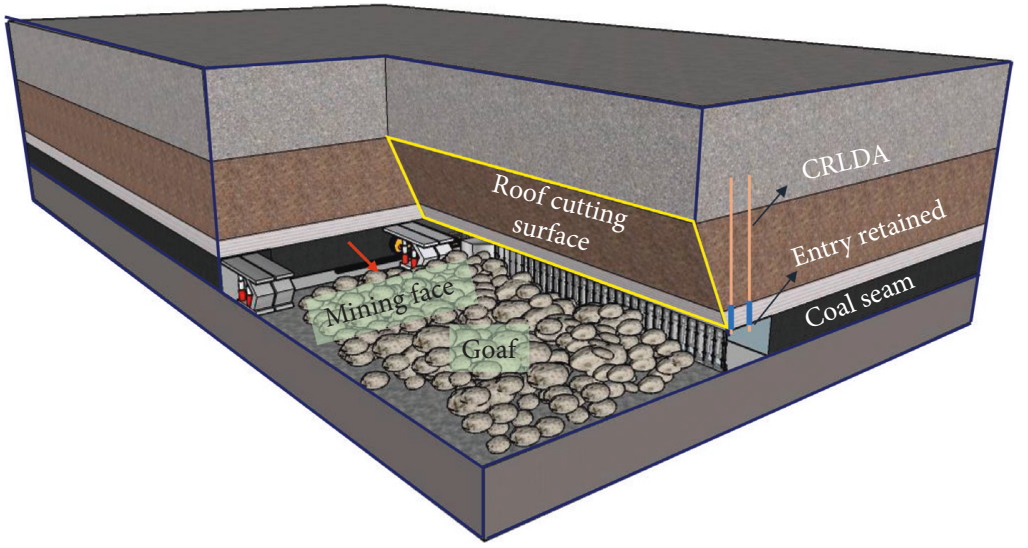

FIGURE 3: Principle of a gob-side entry retained by roof cutting and pressure relief.

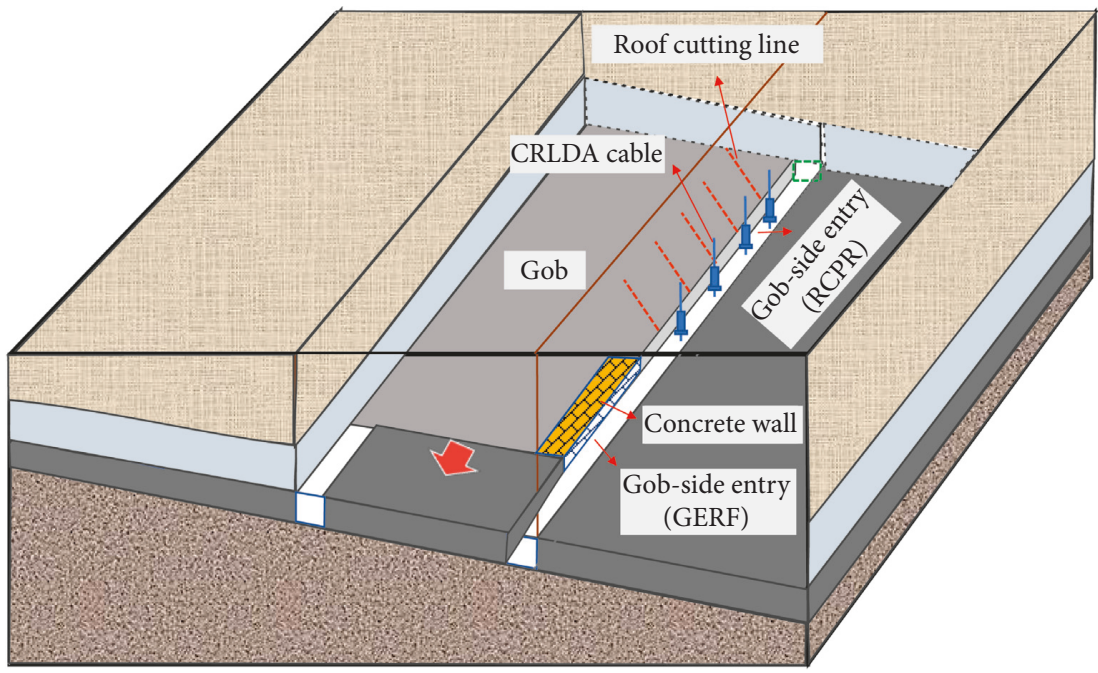

FIGURE 4: Entry layout for the field test.

environmental engineering. The Lagrange algorithm and hybrid-discrete partition technique adopted in FLAC3D can accurately simulate the plastic failure and flow of materials. If the material is deformed or plastic flow occurs under the action of stress, with the deformation of materials, the element mesh will change accordingly, which can effectively simulate the three-dimensional mechanical behavior of rock, soil, or other materials.

3.2.2. Modelling. To analyze the surrounding rock stress distribution of the retained entry by different methods, this paper considers the 011810 trial working face of the Jinfeng Coal Mine as the engineering model. The calculation model is established by using adopting FLAC3D numerical simulation software with a dimension of $360 \times 360 \times 200 \mathrm{~m}$, as shown in Figure 5. Different methods of entry retaining are simulated to distinguish the surrounding rock stress distribution between RCPR entry retaining and the GERF. Scheme 1 refers to the RCPR entry retaining (cutting roof and without leaving pillars), and scheme 2 refers to the GERF (filling along the gob-side of entry after mining) in Figure 5.
The length of the simulated working face is $260 \mathrm{~m}$. The roadway section is $5.0 \times 4.0 \mathrm{~m}$, and the backfill width is $1.0 \mathrm{~m}$. The Mohr-Coulomb model is adopted, and the upper boundary applies a vertical stress of $8.5 \mathrm{MPa}$ to simulate the weight of the overlying strata. The horizontal direction displacements at the front, back, left, and right boundaries are fixed. The physical and mechanical parameters of the rock strata are presented in Table 1 .

\section{Field Application Test}

4.1. Engineering Geological Conditions. The Jinfeng Coal Mine, which is located in the southeast section of Wuzhong City, Ningxia, China, is governed by Fengjigou Yanchi County in Wuzhong City. The minefield covers approximately $36.0776 \mathrm{~km}^{2}$ of land, which is a length of approximately $11.5 \sim 12.0 \mathrm{~km}$ in the north and south and a width of $1.9 \sim 3.5 \mathrm{~km}$ in the east and west. Traffic in the area is dominated by highways, which primarily include S203, GZ25, GZ35, G109, and G307. The long-wall mining method is extensively applied in this mining area, and coal pillars typically remain after this method is employed. However, the 


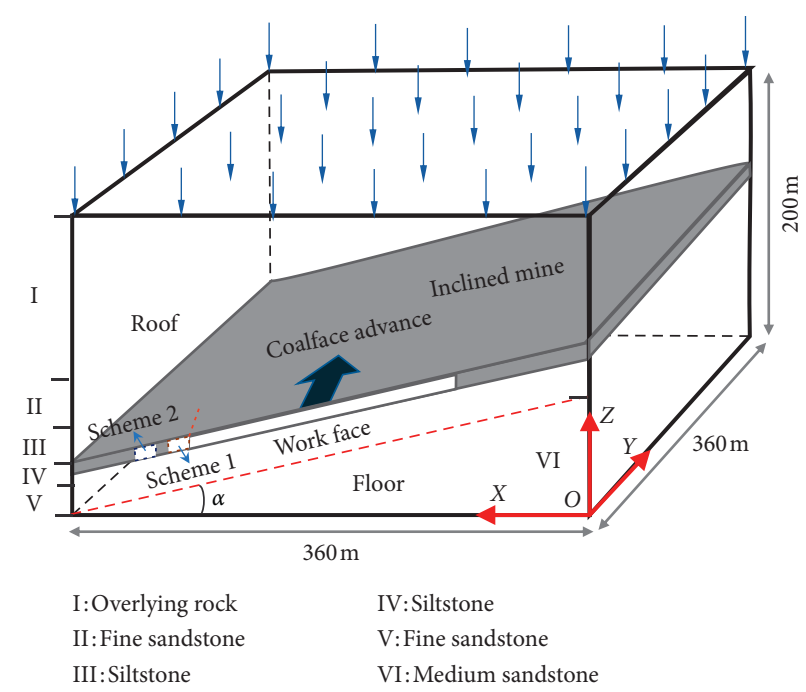

FIgURE 5: Numerical calculation model.

TABLe 1: Physical and mechanical characteristic parameters of an inclined coal seam work face.

\begin{tabular}{|c|c|c|c|c|c|c|c|}
\hline Rock strata & $\begin{array}{l}\text { Density } \\
\left(\mathrm{kg} \cdot \mathrm{m}^{3}\right)\end{array}$ & $\begin{array}{c}\text { Elastic } \\
\text { modulus }(\mathrm{GPa})\end{array}$ & $\begin{array}{l}\text { Poisson } \\
\text { ratio }\end{array}$ & Tensile strength (MPa) & Cohesion (MPa) & Friction angle $\left({ }^{\circ}\right)$ & Thickness (m) \\
\hline Overlying rock & 2600 & 3.34 & 0.30 & 2.32 & 2.05 & 30 & 142 \\
\hline Fine sandstone & 2680 & 5.46 & 0.28 & 2.65 & 2.86 & 34 & 7 \\
\hline Siltstone & 2350 & 1.29 & 0.35 & 1.79 & 1.72 & 27 & 7 \\
\hline Coal & 1350 & 2.90 & 0.36 & 1.40 & 3.20 & 25 & 4 \\
\hline Siltstone & 2300 & 1.15 & 0.33 & 1.54 & 1.40 & 27 & 2 \\
\hline Fine sandstone & 2540 & 3.82 & 0.27 & 1.95 & 2.23 & 32 & 6 \\
\hline Medium sandstone & 2620 & 3.35 & 0.29 & 2.32 & 1.97 & 31 & 32 \\
\hline
\end{tabular}

residual coal pillars will cause a large loss of resources and tension between the mining and excavation continuance. The implementation of nonpillar mining technology in this mining area can improve the coal recovery ratio and relieve the tension between the mining and excavation continuance. This method has great significance for the sustainable development of the mining area. The location of the test site is presented in Figure 6.

4.1.1. Working Face Conditions. The 011810 working face is located at level +1151 , coal 18 and mining area 1 , and the buried depth of $214.06 \sim 328.9 \mathrm{~m}$. The strike length is $1023.3 \mathrm{~m}$. The mining length is $550 \mathrm{~m}$. The dip is $12 \sim 32^{\circ}$ with an average of $22^{\circ}$, and the working face has a length of $260 \mathrm{~m}$. The coal seam thickness ranges from 3.3 to $4.2 \mathrm{~m}$ with an average thickness of $3.75 \mathrm{~m}$. The 011810 working face layout and the entry retaining position are presented in Figure 7.

4.1.2. Coal Seam and Strata. Based on the drilling data and geological documents revealed in the 011810 head entry driving process, the 18 th coal roof and floor strata are composed of fine sandstones and siltstones and have conformable contact with each other.

The immediate roof of the 011810 headway is constructed of siltstones with a thickness of $7.1 \mathrm{~m}$. The main roof is constructed of fine sandstone with a thickness of $6.8 \mathrm{~m}$. The immediate floor is constructed of $1.3 \mathrm{~m}$ thick siltstones. The main floor is constructed of fine sandstones with a thickness of $5.5 \mathrm{~m}$. The lithology of the rock layers near the coal is shown in Figure 8.

\subsection{Parameter Design for Different Entry Retained Methods}

\subsubsection{Engineering Parameters for Gob-Side Entry Retained by $R C P R$}

(1) Roof Cutting Design. The design of presplitting cutting parameters needs to be comprehensively considered. The collapsed rock should fully fill the gob space under the broken expand function. The critical design formula of the roof cutting depth $(H)$ is expressed as follows [24]:

$$
H=\frac{\left(H_{m}-\Delta H_{1}-\Delta H_{2}\right)}{(K-1)},
$$

where $H_{\mathrm{m}}$ is the mining height $(\mathrm{m}), \Delta H_{1}$ is the roof subsidence $(\mathrm{m}), \Delta H_{2}$ is the floor heaves $(\mathrm{m})$, and $K$ is the broken expand coefficient.

According to the field measurement technique proposed in the literature [25], this design assumes that $K$ is 1.38 and the mining height of 011810 face is $3.8 \mathrm{~m}$ without considering floor heaves and roof subsidence. The cutting 


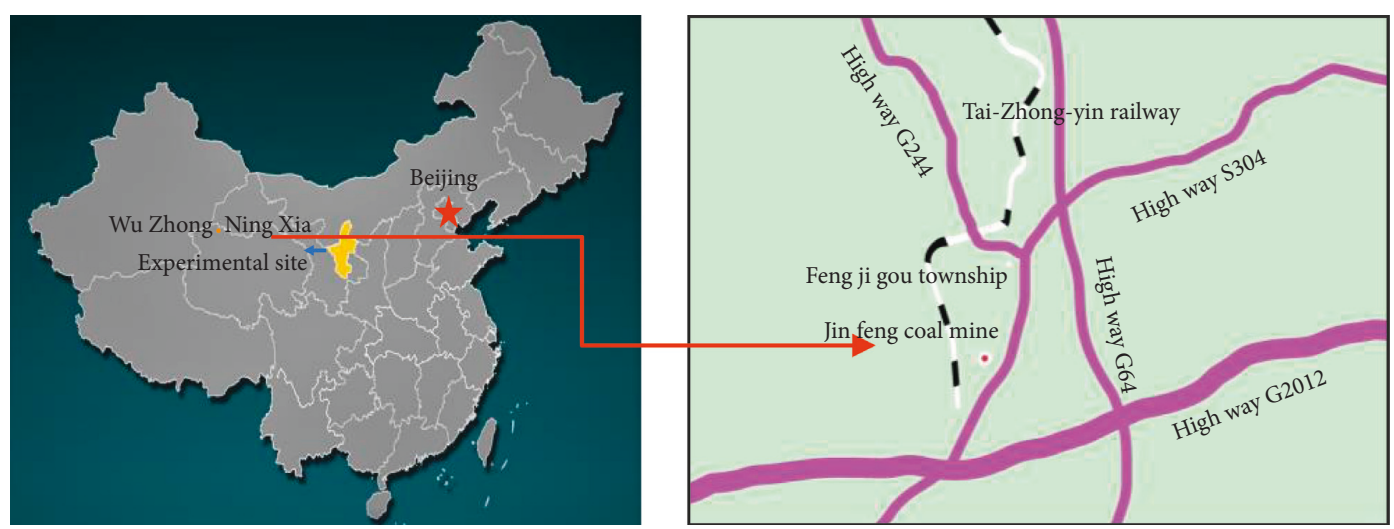

Figure 6: Location of the test site.

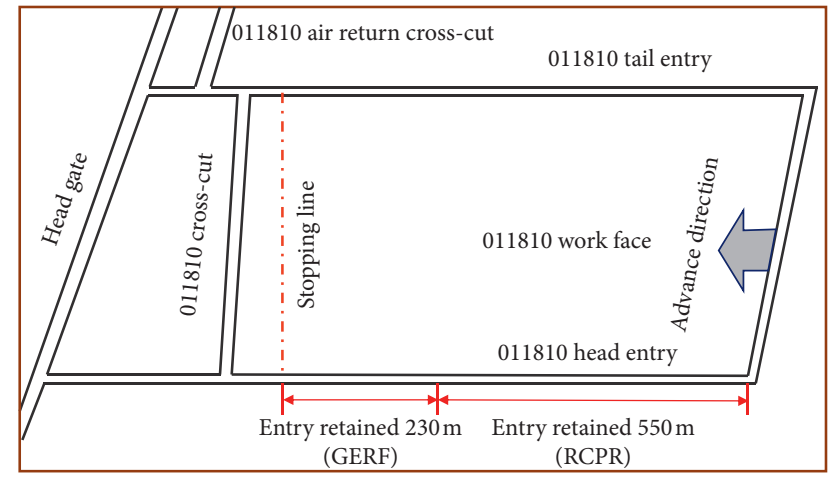

FIGURE 7: 011810 working face layout and the entry retaining position.

\begin{tabular}{|c|c|c|c|}
\hline Columnar & Thickness (m) & Lithology & Remarks \\
\hline & 2.7 & Siltstone & \multirow{2}{*}{ Main roof } \\
\hline & 6.8 & Fine sandstone & \\
\hline & 7.1 & Siltstone & Immediate roof \\
\hline & 4.3 & Coal & Coal seam 18 \\
\hline & 1.3 & Siltstone & Immediate floor \\
\hline & 5.4 & Fine sandstone & Main floor \\
\hline
\end{tabular}

FIGURE 8: Lithology of the rock layers near the coal.

depth is $9 \mathrm{~m}$ based on the calculation results and roof lithology.

The roof cutting angle is $20^{\circ}$ with a height of $9 \mathrm{~m}$ in this area to prevent the pressure generated by gangue downslide. The collapsed gangues near the cutting line can rapidly form an equivalent filling body to support the key strata of the roof and buffer the impact in the lateral, as shown in Figure 9.

(2) Constant Resistance Anchor Cable Design. To guarantee the stability of the gob-side entry during the process of roof cutting and periodic weighting, a CRLDA cable is used to strengthen the entry support before conducting the roof cutting. According to the original roadway deformation and mine pressure situations, three series of constant resistance large deformation anchor cables were designed. Series one at the side of the cutting line: the array pitch is $1000 \mathrm{~mm}$, $500 \mathrm{~mm}$ from the entry side and $90^{\circ}$ angle with the horizon. Series two in the middle of the entry: the array pitch is $1500 \mathrm{~mm}$ and $90^{\circ}$ angle with the horizon. Series three at the integrated coal side: the array pitch is $3000 \mathrm{~mm}, 500 \mathrm{~mm}$ from the integrated coal side and $10^{\circ}$ angle with the plumb line. The diameter of the constant resistance and large deformation anchor cable is $21.8 \mathrm{~mm}$. Based on the cutting parameter and the position of the stable strata in the roadway, the anchor cable length is assumed to be $12.3 \mathrm{~m}$. A cross-sectional diagram is designed and shown in Figure 10.

4.2.2. Engineering Parameters for Gob-Side Entry Retained by GERF. The gob-side entry retaining by the GERF adopts the method of flexible formwork and pump concreted, and the roadside supporting load is calculated by the method of separated rock block proposed by British scholar Whittaker. The theoretical calculation method considers that the goaf provides a free surface for the roof block. Because the rock block is stratified, an abscission layer may occur at the height $H$, which causes rock fracturing along the coal body with the angle $\theta$ and enables a completely free state, which becomes the load of the support body. Thus, a mechanical model of roadside support is established, as shown in Figure 11.

(1) Load and Width of Roadside Support. The load calculation formula is expressed as follows:

$$
q=\frac{8 h \operatorname{tg} \theta+2\left(b_{B}+x+b_{C}\right)}{x} \times \frac{h\left(b_{B}+x+b_{C}\right) \gamma_{s} \times \cos \alpha}{b_{B}+0.5 x},
$$

where $q$ is the load of the supporting body; $b_{1}$ is the distance from the inner side of the support body to the coal wall, value $4 \mathrm{~m} ; x$ is the width of the support body; $b_{2}$ is the span of the hanging roof outside of the support, when the roof collapse time is $0 ; \gamma_{s}$ is the gravity of the rock mass, and the average gravity of the overlying strata is $24 \mathrm{kN} / \mathrm{m}^{3} ; h$ is the support height, and the height of the concreted wall is $3.8 \mathrm{~m} ; \theta$ is the shear angle, which is $26^{\circ}$ based on experience; and $\alpha$ is the coal seam dip, with an average dip of $22^{\circ}$. 


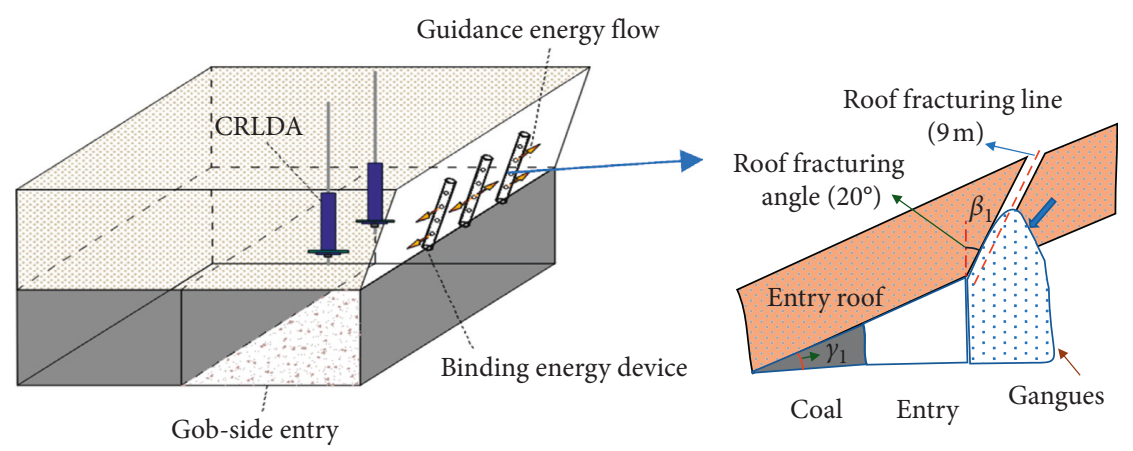

Figure 9: Principle of roof cutting and the parameters.

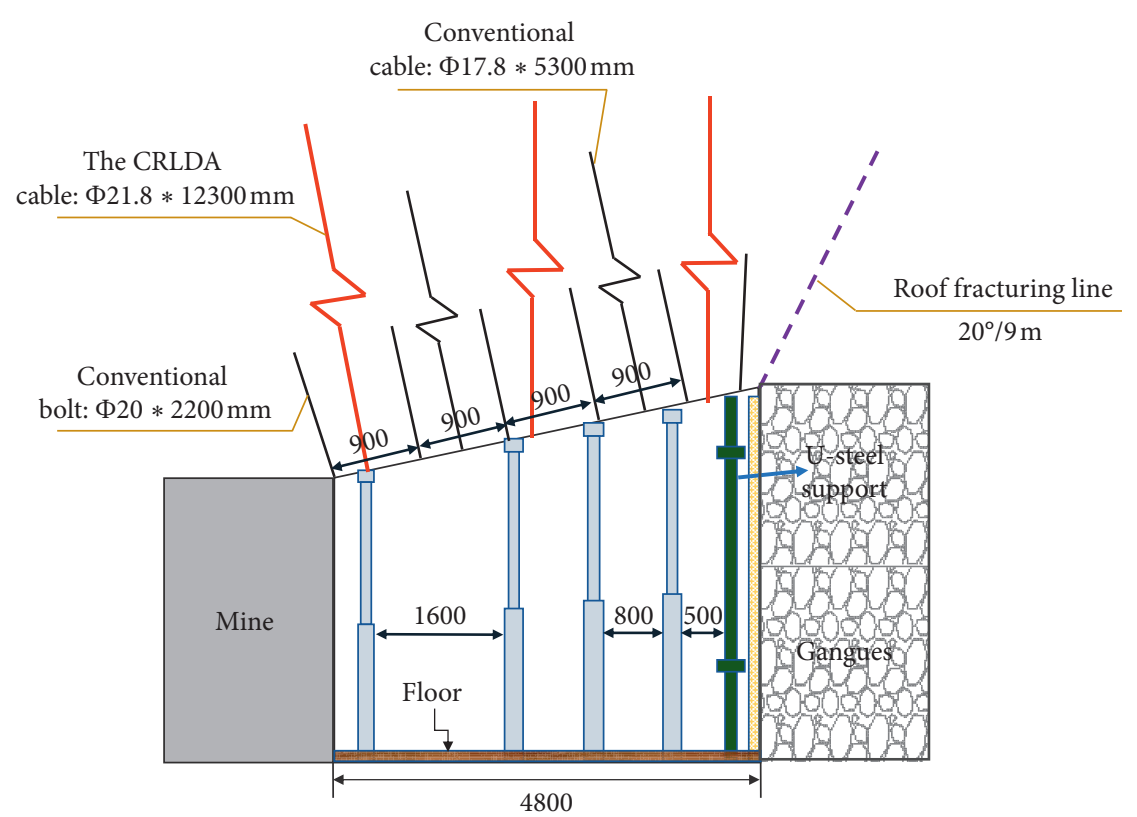

FIgURE 10: Constant resistance anchor cable and lateral gangue support parameters.

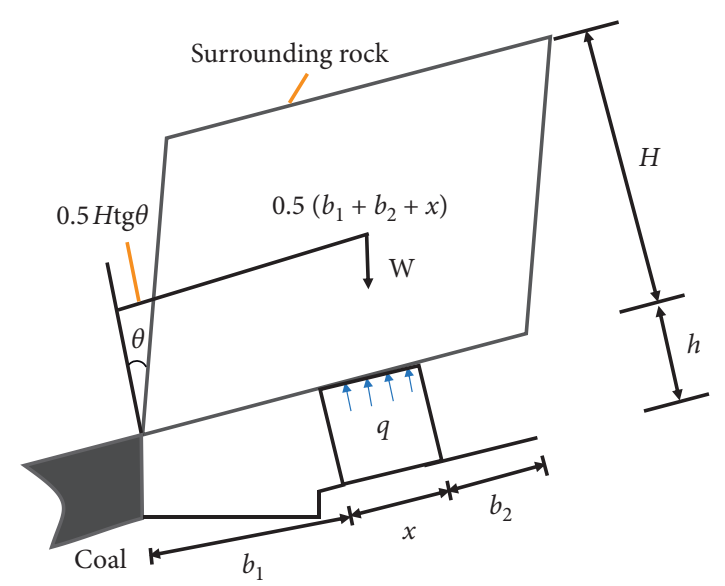

FIgURE 11: Mechanical model of gob-side retained by flexible formwork and pump concreted.
According to the calculation results, when the thickness of support is $1 \mathrm{~m}$, the load of the support body is

$$
\begin{aligned}
q= & \frac{8 \times 3 \operatorname{tg} 26+2 \times(4+1+0)}{1} \\
& \times \frac{3.8 \times(4+1+0) \times 24 \times \cos 22}{4+0.5 \times 1}=2.03 \mathrm{MPa} .
\end{aligned}
$$

Considering the factors of dynamic load, the dynamic load coefficient value is $3, q=6.09 \mathrm{MPa}$, and the support load of unit length and a support thickness of $1 \mathrm{~m}$ is $N_{1}=6090 \mathrm{kN}$.

(2) Checking Calculation of Bearing Capacity. The support with unit length and thickness of $1 \mathrm{~m}$ is regarded as the model of the axially compressed column to calculate the bearing capacity of the normal section. The height of the 
model column is $3.8 \mathrm{~m}$, the length of the short side is $1 \mathrm{~m}$, and the slenderness ratio of the component is $3.8 / 1=3.8$. By referring to the calculation method of an axially compressed component, the component stability coefficient $\phi$ is 1.0.

The bearing capacity of the model column is calculated as

$$
N=0.9 \varphi \times f_{c} A,
$$

where $N$ is the bearing capacity of the supporting body, $\phi$ is the stability coefficient of the component, value $1.0 ; f_{c}$ is the concrete axis ultimate compressive strength, $16.8 \mathrm{~N} / \mathrm{mm}^{2}$ for C25; and $A$ is the cross-sectional area, $1000 \times 1000 \mathrm{~mm}^{2}$. follows:

The bearing capacity of the support body is calculated as

$$
N=0.9 \times 1.0 \times 16.8 \times 1000 \times 1000=15120 \mathrm{kN},
$$

which is considerably higher than $6090 \mathrm{kN}$. Therefore, the bearing capacity of the support body satisfies the requirements.

(3) Concrete Proportioning and Flexible Formwork Design. Flexible formwork pumping concrete technology utilizes the water permeability and impermeable cement mortar characteristics of flexible formwork, which requires excellent fluidity and high strength of concrete. The sand ratio of the flexible formwork pumping concrete design is larger than that of ordinary concrete design, usually $40 \%-45 \%$. The maximum particle size of stones should be compatible with the diameter of the conveyor pipe and the thickness of the flexible formwork; the largest particle size is usually less than $20 \mathrm{~mm}, 5-16 \mathrm{~mm}$. The water-cement ratio of the mixing concrete should range from 0.5 to 0.6 . The slump should range from 180 to $220 \mathrm{~mm}$.

In this design that uses C25 concrete, the concrete proportioning is as shown in Table 2.

The design of the flexible formwork dimension should comprehensively consider the size of the entry section and the construction conditions. Considering the construction error, the height of the flexible formwork is $4 \mathrm{~m}$, the length is $3 \mathrm{~m}$, and the thickness is $1 \mathrm{~m}$. To improve the strength of the concrete, 6 anchor bolts are installed in each flexible formwork unit. The flexible formwork is shown in Figure 12.

4.3. Field Application. A field application was performed at the 011810 working face of the Jinfeng Mine in Ningxia Province, China, which is owned by the Ningmei Group. After mining, the entry was retained to be reused for the 011812 mining panel.

At the 011810 working face, the gob-side entry with a length of $780 \mathrm{~m}$ was successfully retained, of which $550 \mathrm{~m}$ adopted RCPR and $230 \mathrm{~m}$ adopted the GERF method. Figure 13 shows the construction process of gob-side entry retaining by RCPR and the gob-side entry effect by this method. The process of RCPR can be divided into three steps: (a) in stage A premining, a CRLDA is installed to reinforce the entry roof and the roof cutting is performed; (b) in stage B after mining, a temporary support, metal nets, and $U$-steel are installed behind the working face to prevent
TABLE 2: Concrete proportioning for flexible formwork pumping.

\begin{tabular}{lcccccc}
\hline Material & Concrete & Sand & Gravel & Water & Fly ash & Additive \\
\hline Quality (kg) & 450 & 800 & 850 & 226 & 140 & 1.2 \\
\hline
\end{tabular}

the gangue from collapsing into the retained entry; and (c) in stage $\mathrm{C}$, when the goaf roof completely collapses and the surrounding rock of the retained entry is stable, the entry is completely retained.

The construction process of the gob-side entry retaining by the GERF and the gob-side entry effect by this method are shown in Figure 14. This construction process can also be divided into three steps: (I) supporting the working space and hanging flexible formwork, (II) concrete preparation and grouting, and (III) when the goaf roof completely collapses and the surrounding rock of the retained entry is stable, the entry is completely retained.

When using different methods for gob-side entry retaining, both methods can achieve entry retaining safety. However, the surrounding rock deformation of the gob-side entry differed from the final entry outline of the two methods. The labor intensity of the workers differs between the two methods because gob-side entry retaining by RCPR divides the entire construction process into two parts: premining and postmining. Fewer parallel working procedures exists between retaining entry and mining, and the construction process of gob-side entry retaining by the GERF simultaneously occurs with mining. Thus, the construction intensive degree is relatively high. In terms of the economic benefits, the costs of each $1 \mathrm{~m}$ of gob-side entry retaining by RCPR and the GERF was 1094 USD and 1173 USD, respectively.

\section{Results and Discussion}

5.1. Deformation of the Entry Surroundings. To study the effects of the gob-side entry retaining by different methods, the deformation law of the surrounding rock of the gob-side entry and the hydraulic support pressure near the gob-side entry were monitored. The deformation values of the surrounding rock, including the roof subsidence $\left(P-P_{0}\right.$, $\left.E-E_{0}\right)$, floor heave, and entry sides displacement $\left(M-M_{0}\right)$ were measured by the surrounding rock displacement monitor and steel tape. The hydraulic support pressure was monitored by a pressure sensor. Figure 15 shows the mine pressure monitoring methods and layout.

As seen in Figure 16, the surrounding rock deformation of the gob-side entry retaining by RCPR reveals three characteristic areas that can be divided into three stages: first stage (stage I: 0 75 m): the deformation of the entry presented an increasing tendency and rapidly increased with the advance of the working face; second stage (stage I: $75 \sim 200 \mathrm{~m}$ ): the deformation of the entry continued to increase, and the velocity of deformation was distinctly reduced; and third stage (stage I: 200 300 m): the deformation tended to be stable. The final deformation values of the roof subsidence $\left(E-E_{0}\right)$, roof subsidence $\left(P-P_{0}\right)$, floor heave, 


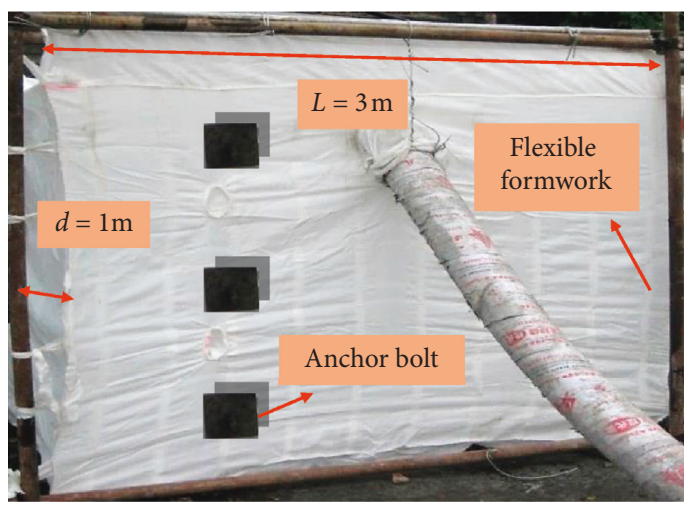

(a)

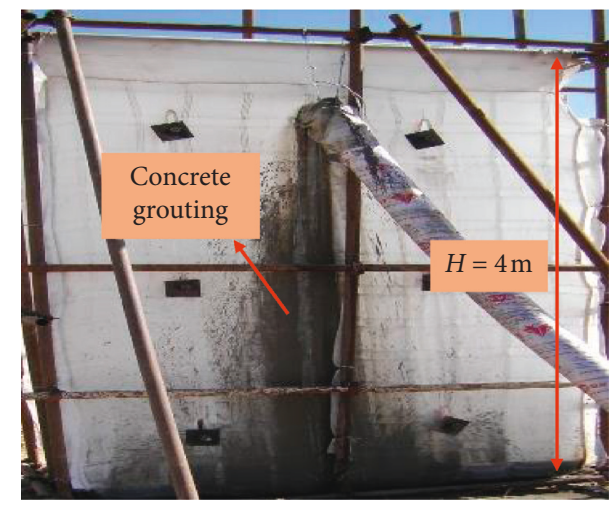

(b)

Figure 12: Flexible formwork test on the ground.
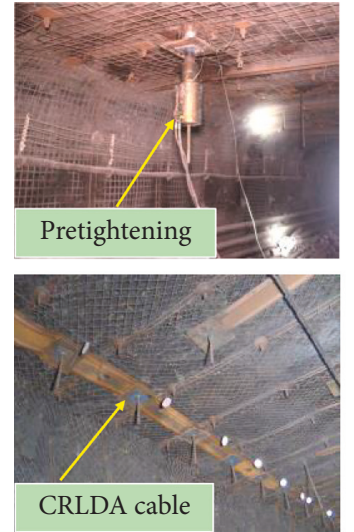

(a)

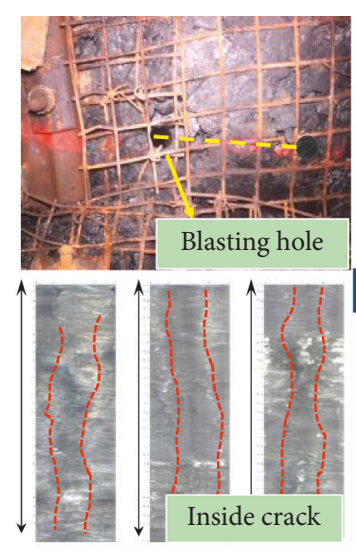

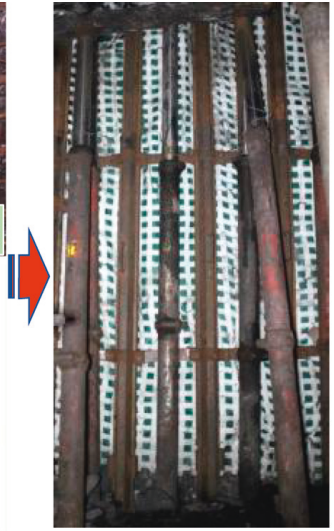

(b)

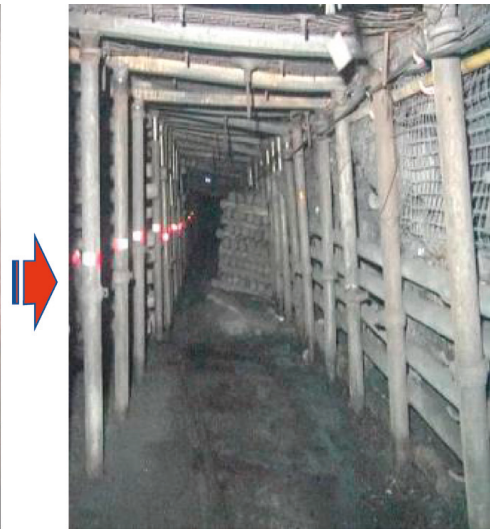

(c)

FIGURE 13: Technological process of the entry retained by RCPR.
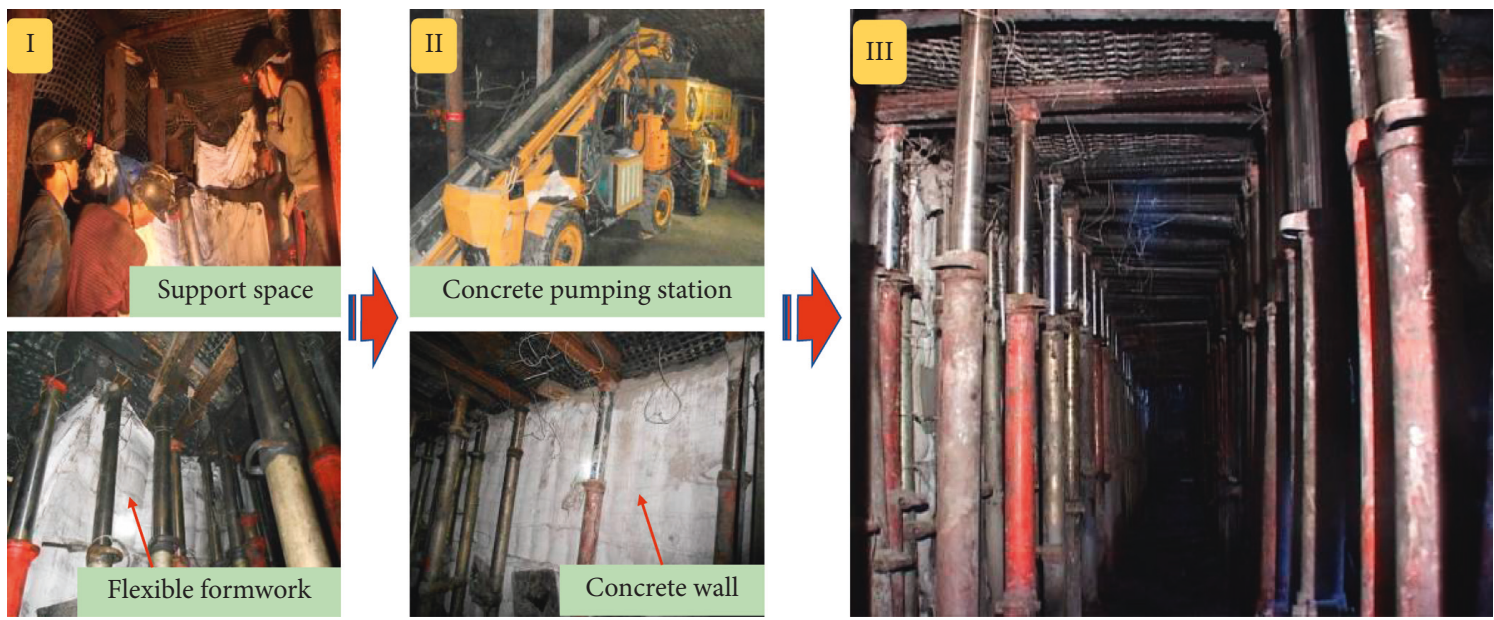

FIGURE 14: Technological process of the entry retained by GERF.

and entry sides displacement were $263 \mathrm{~mm}, 164 \mathrm{~mm}, 88 \mathrm{~mm}$, and $126 \mathrm{~mm}$, respectively.

As shown in Figure 17, the surrounding rock deformation of gob-side entry retaining by the GERF exhibits the same rule as RCPR and can be divided into three stages: first stage (stage I: $0 \sim 100 \mathrm{~m}$ ), second stage (stage I:
$100 \sim 225 \mathrm{~m}$ ), and third stage (stage I: $225 \sim 300 \mathrm{~m}$ ).Compare with stage I of the gob-side entry retained by RCPR, the deformation distance and the maximum deformation rate increased. Deformation of the surrounding rock tends to be stable $225 \mathrm{~m}$ behind the working face. The final deformation values of the roof subsidence $\left(E-E_{0}\right)$, roof subsidence $\left(P-P_{0}\right)$, 


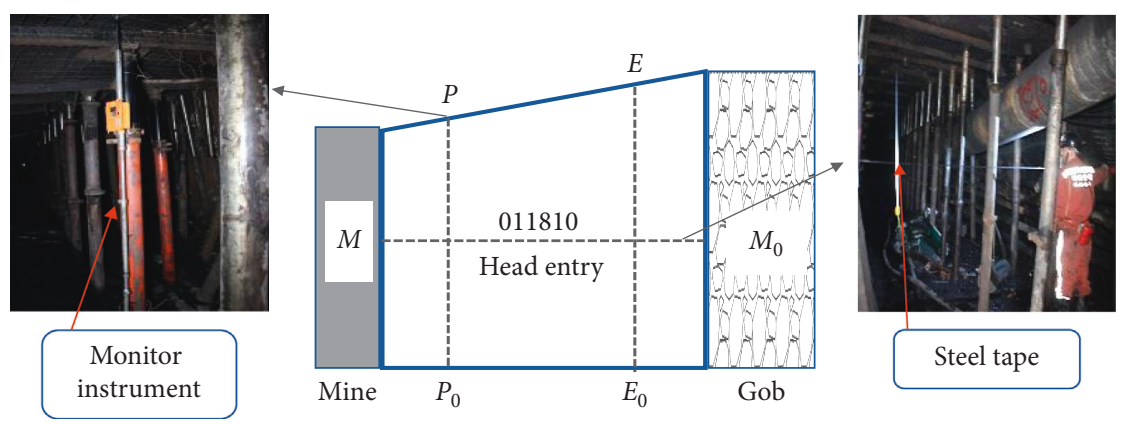

Figure 15: Mine pressure monitoring methods and layout.

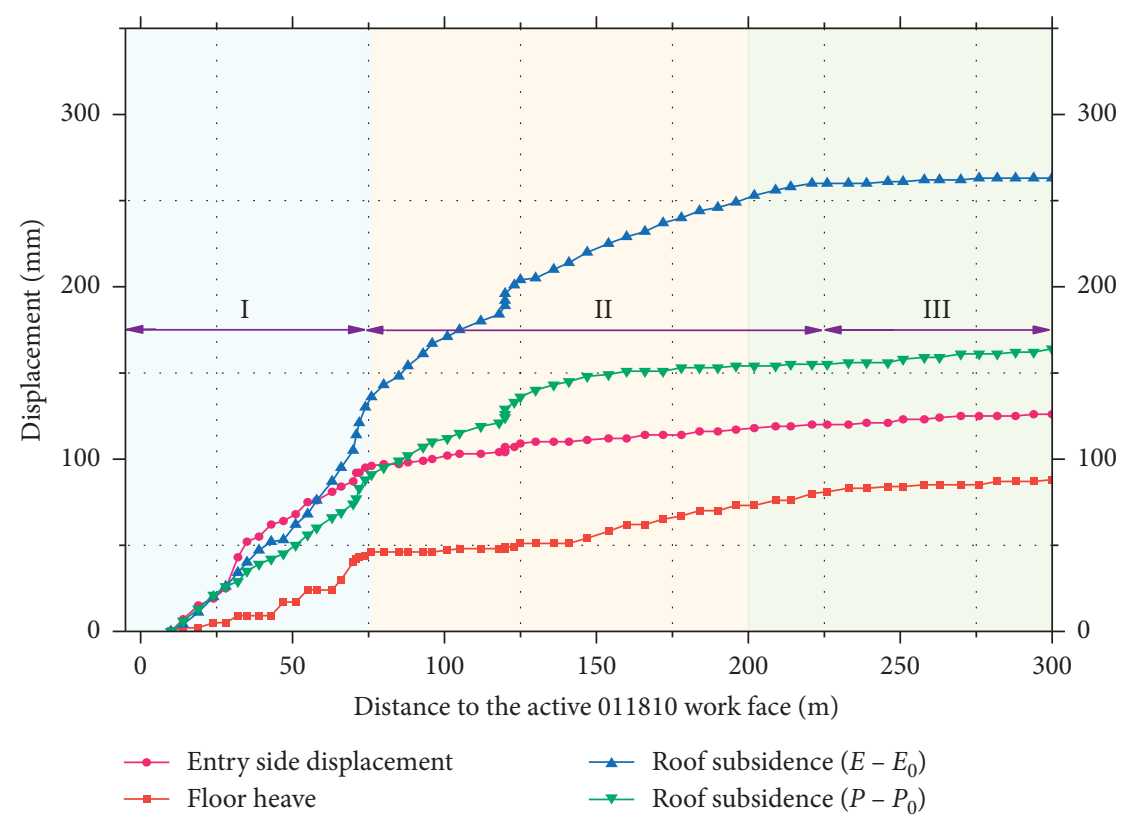

FIGURE 16: Surrounding rock deformation of the gob-side entry retaining by RCPR.

floor heave, and entry sides displacement were $549 \mathrm{~mm}$, $271 \mathrm{~mm}, 336 \mathrm{~mm}$, and $216 \mathrm{~mm}$, respectively. Compared with the deformation of the gob-side entry retained by RCPR, the maximum deformation value increased, and the increase in the floor heave and roof subsidence were particularly distinct.

The gob-side entry using different retained methods can satisfy the ventilation demand of the next working face. The surrounding rock deformation of gob-side entry retaining by different methods was nonharmonious, and the roof subsidence $\left(E-E_{0}\right)>\left(P-P_{0}\right)$.

5.2. Pressure of the Stope. The hydraulic support pressure was monitored by using a pressure sensor. Figure 18 shows the mine pressure monitoring methods and layout.

The hydraulic support pressure near the retained entry is selected to analyze the strata behaviors, as shown in Figure 19. The mining distance $450-550 \mathrm{~m}$ belongs to the gobside entry retained by RCPR, and 550-650 m applied to part of the gob-side entry retained by the GERF, as noted by the curves. The support pressure peak at the gob-side entry retained by RCPR is $32.2 \mathrm{MPa}$ with an average of $28.8 \mathrm{MPa}$.
The support pressure peak at the gob-side entry retained by the GERF is $38.7 \mathrm{MPa}$ with an average of $33.6 \mathrm{MPa}$. The support pressure peak is decreased by $6.5 \mathrm{MPa}$, which is reduced by approximately $16.8 \%$. The average resistance is decreased by $4.8 \mathrm{MPa}$, which is reduced by approximately $14.3 \%$. The periodic weighting length of the gob-side entry retained by RCPR and GERF is $21 \mathrm{~m}$ and $25 \mathrm{~m}$, respectively, and the periodic weighting length increased by approximately $19 \%$. The monitoring data indicate that roof cutting decreased the weighting intensity and weakened the support pressure to some extent due to the gob-side entry retaining by RCPR.

The hydraulic support pressure in the middle of the working face is shown in Figure 20. The mining distance from 450 to $550 \mathrm{~m}$ belongs to the gob-side entry retained by $\mathrm{RCPR}$, and the mining distance from 550 to $650 \mathrm{~m}$ was part of the gob-side entry retained by GERF, as noted by the curves. The support pressure peak at the gob-side entry retained by RCPR is $45.3 \mathrm{MPa}$ with an average of $34.4 \mathrm{MPa}$. The support pressure peak at the gob-side entry retained by GERF is $44.8 \mathrm{MPa}$ with an average of $33.5 \mathrm{MPa}$. The support pressure peak is the same. The periodic weighting length of 


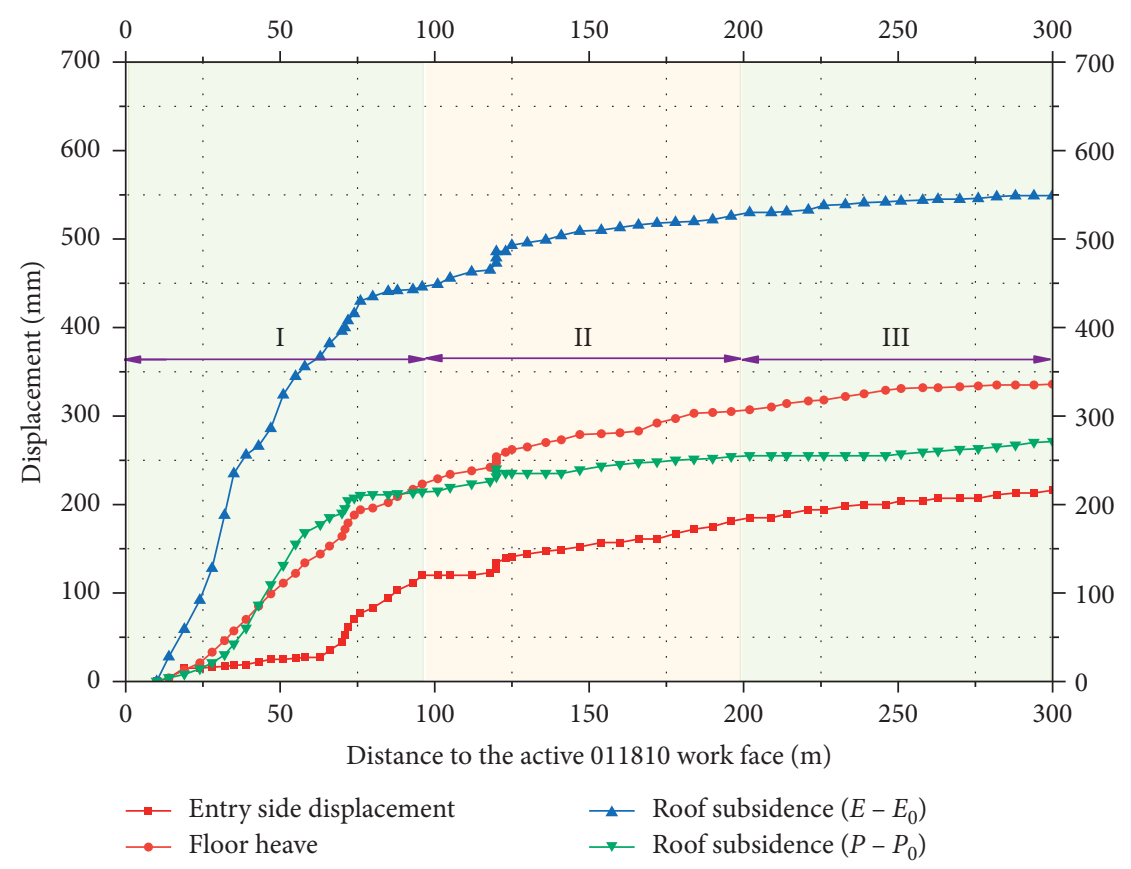

FIGURE 17: Surrounding rock deformation of the gob-side entry retaining by GERF.

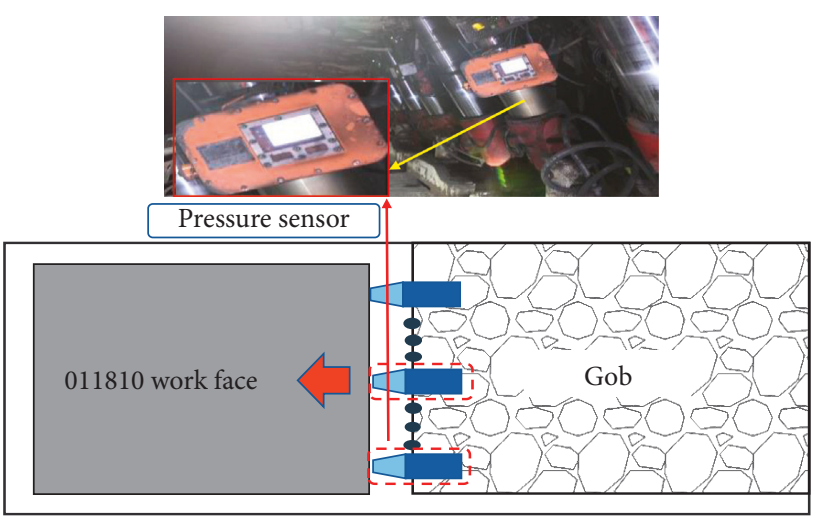

011810 head entry

FIGURE 18: Mine pressure monitoring methods and layout.

the gob-side entry retained by RCPR and GERF is $17 \mathrm{~m}$ and $19 \mathrm{~m}$, respectively. The monitoring data indicate that roof cutting caused a decrease in the weighting intensity and weakened the support pressure only within a certain range, beyond which the pressure-relief effect is not distinct.

5.3. Stress Field around the Entry. Excavation is performed by steps in the simulation. When the face advance is $300 \mathrm{~m}$, the stress nephogram near the gob-side entry and working face can be obtained by the vertical stress data on the interface between the coal seam and the roof, as shown in Figure 21.

The upper roof strata are fractured into rocks after mining, causing the stress on the coal seam near gob-side entry to be redistributed. The surrounding rock stress tends to be stable when the roof contacts with gangues. With regards to the filling gob-side entry retaining, the gob cannot be completely filled with gangues. Therefore, the roof has a large subsidence space, which leads to obvious stress concentration in front of the mining face and in the coal side of gob-side entry. In particular, the "sharp corner of stress" will appear when the advanced stress and the concentrated stress caused by entry excavation are superimposed, as shown in Figure 21(a).

Compared with the filling gob-side entry retaining, RCPR gob-side entry retaining first conducts directional roof cutting on the gob side of entry, and the roof mass near the cutting line collapses rapidly and completely fills the gob after mining, which can cause the key block to rapidly make contact with the gangues to restrain the rotating subsidence intensity. In these conditions, the scope and intensity of the concentrated stress in front of the working face and on the coal side of the gob-side entry are distinctly decreased, as shown in Figure 21(b). Therefore, RCPR can optimize the stress environment of the gob-side entry surrounding rock, which is more beneficial for controlling the surrounding rock deformation and improving the stability of the gob-side entry.

To further analyze the stress distribution in the front and lateral sides of the working face, the stress distribution curves of two entry retaining methods were obtained based on the vertical stress at measuring lines $a$ and $b$, as shown in Figure 21. Measuring line $a$ is located in front of and perpendicular to the working face. The line is $5 \mathrm{~m}$ from the gobside entry. Conversely, measuring line $b$ is located at the back of and parallel to the working face. The line is $10 \mathrm{~m}$ behind the working face.

The stress distribution curves clearly demonstrate that the vertical stress distribution with respect to the two gob- 


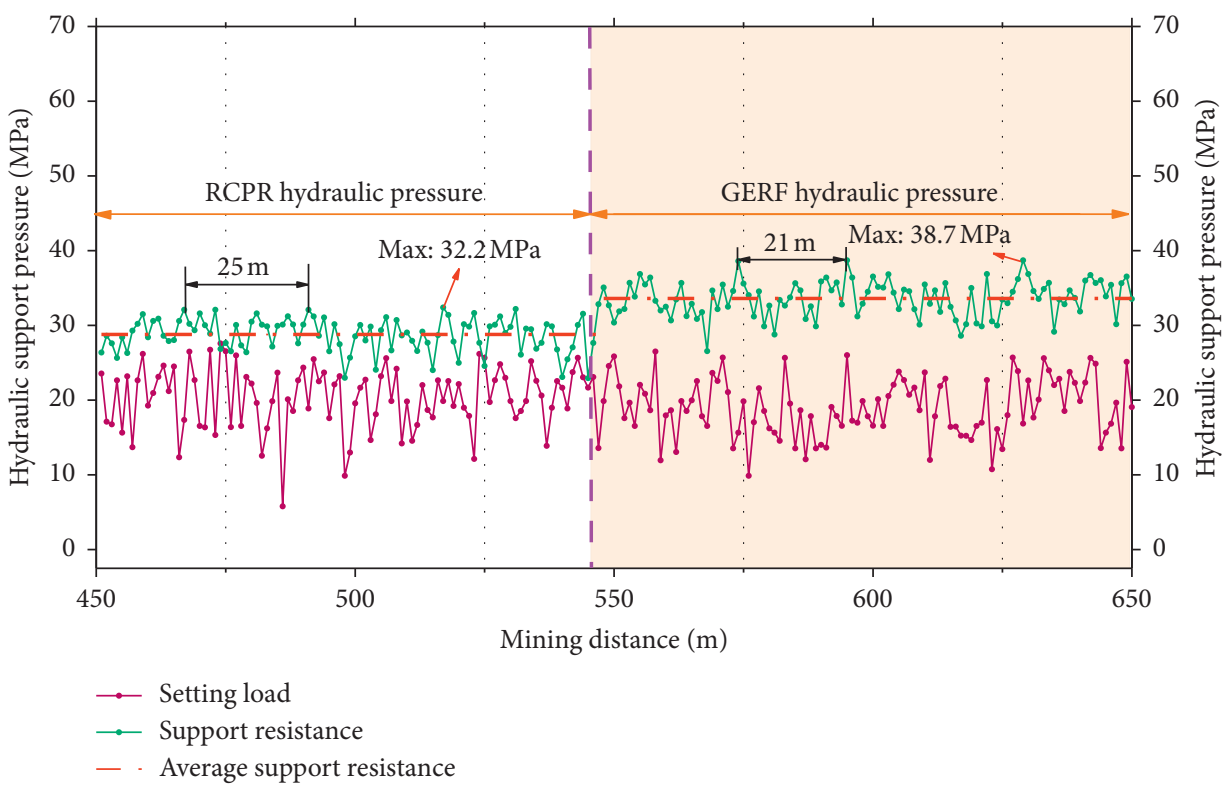

FIGURE 19: Hydraulic support pressure near the retained entry.

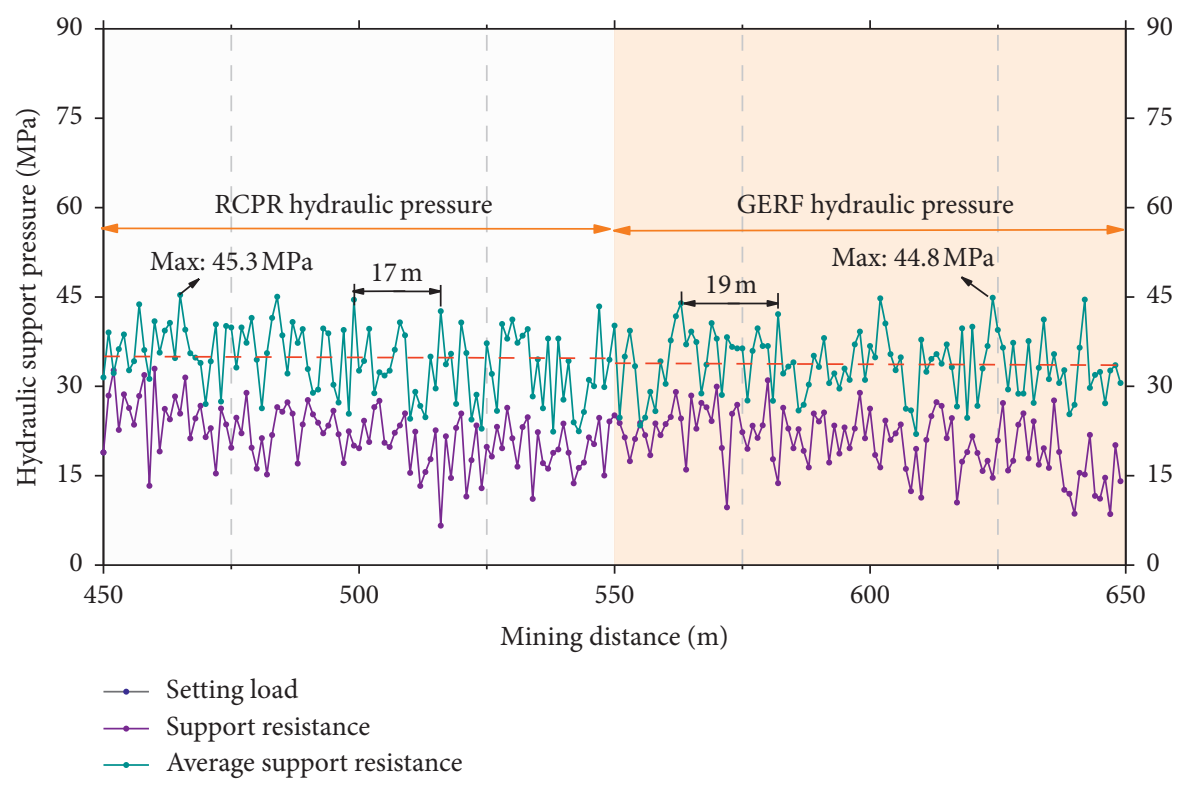

FIGURE 20: Hydraulic support pressure in the middle of working face.

side entry retaining methods was consistent. As the distance from the working face increases, a trend of increasing and then decreasing was observed. The maximum value is demonstrated to be approximately $5 \mathrm{~m}$ in advance of the working face. The stress peak of the gob-side entry retaining by filling is $22.86 \mathrm{MPa}$, whereas that of the entry retaining by $\mathrm{RCPR}$ is $17.80 \mathrm{MPa}$. This value is decreased by $22.1 \%$ compared with the former value, as presented in Figure 22(a). Regarding the lateral aspect of the working face, the stress peak of gob-side entry retaining by filling is noted at approximately $5 \mathrm{~m}$ inside the coal with a maximum value of $25.16 \mathrm{MPa}$. Conversely, entry retaining by RCPR has a smooth stress distribution. The maximum stress value of 12.72 $\mathrm{MPa}$ is noted approximately $6-8 \mathrm{~m}$ inside the coal.
This value is decreased by $49.4 \%$ compared with filling gobside entry retaining, as presented in Figure 22(b).

The analysis indicates that the rotating subsidence of the upper roof can effectively be controlled by RCPR, which changed the collapse height and the broken expanded state. Thus, the stress of the surrounding rock near the entry was reduced, which was more beneficial to ensuring the stability of the entry.

\section{Conclusions}

Nonpillar mining has an important role in the sustainable exploitation of coal resources. Currently, the gob-side entry retaining is the main method for achieving nonpillar mining. 


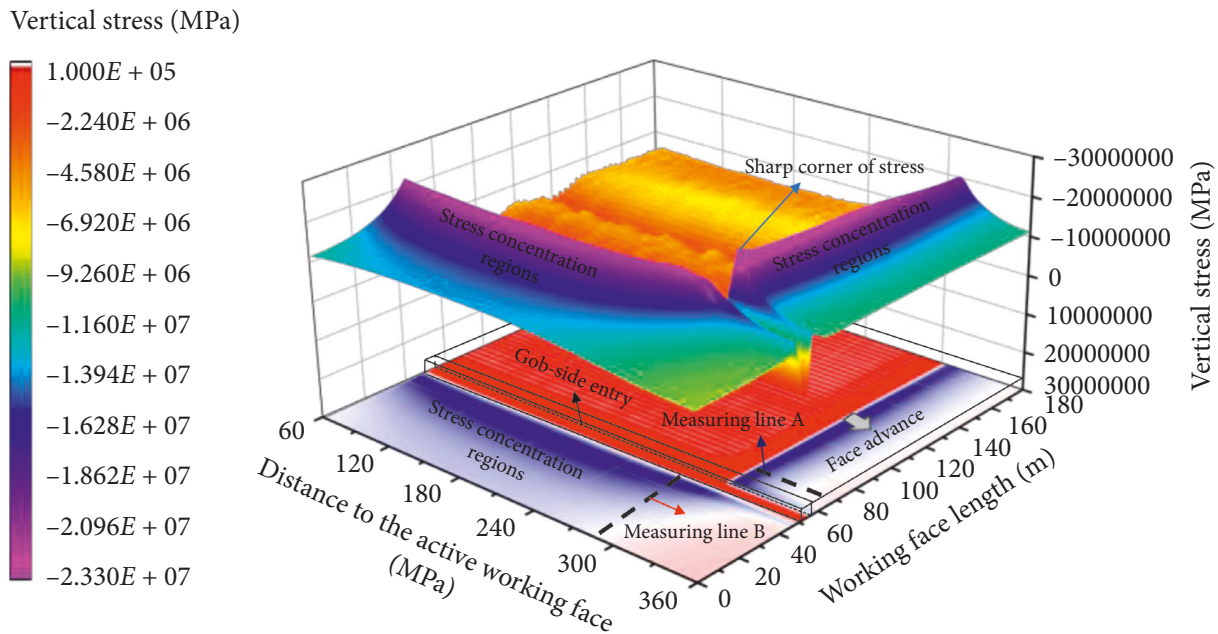

(a)

Vertical stress $(\mathrm{MPa})$
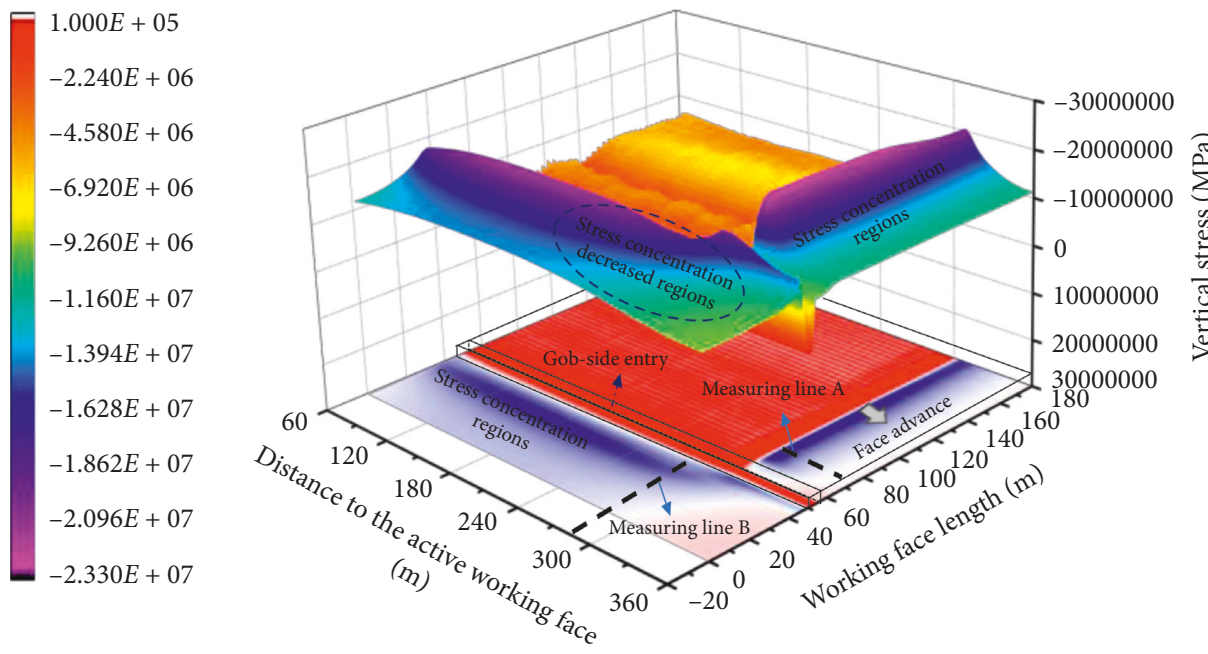

(b)

FIGURE 21: Vertical stress nephogram of two gob-side entry retaining methods: (a) GERF; (b) RCPR.

After several years of exploration by scholars, two mature methods of gob-side entry retaining exist: RCPR and GERF. The two methods are based on different surrounding rock control concepts of retaining entry. Thus, the effect of retained entry and the deformation law of surrounding rock differ. In this paper, the engineering parameters for two different gob-side entry retaining methods were designed and implemented for the same geological condition, and the effect of retained entry is comprehensively evaluated. The following major conclusions were obtained:

(1) The gob-side entry retained by two methods can satisfy the requirement of the next panel, and the design concept differs. Gob-side entry retaining by $\mathrm{RCPR}$ is an active pressure-relieving method. In this method, the surrounding rock structure and stress environment of a gob-side entry changes. Gob-side entry retaining by GERF is a passive pressure- resisting method of retaining entry by laying a filling body to support and resist the entry roof. The RCPR method divides the entry retaining step into two stages: premining and postmining. The labor intensive degree of an entry retaining project is dispersed. The main working procedure of the GERF is performed during the face mining. The difference between the total labor intensity is small, and the parallel working procedure of RCPR with mining work is small.

(2) The surrounding rock deformation of gob-side entry retaining by RCPR reveals three characteristic areas that can be divided into three stages. In the first stage (stage I: 0 75 m), the deformation of the entry presented an increasing tendency and rapidly increased with the advance of the working face. In the second stage (stage II: 75 200 m), the 


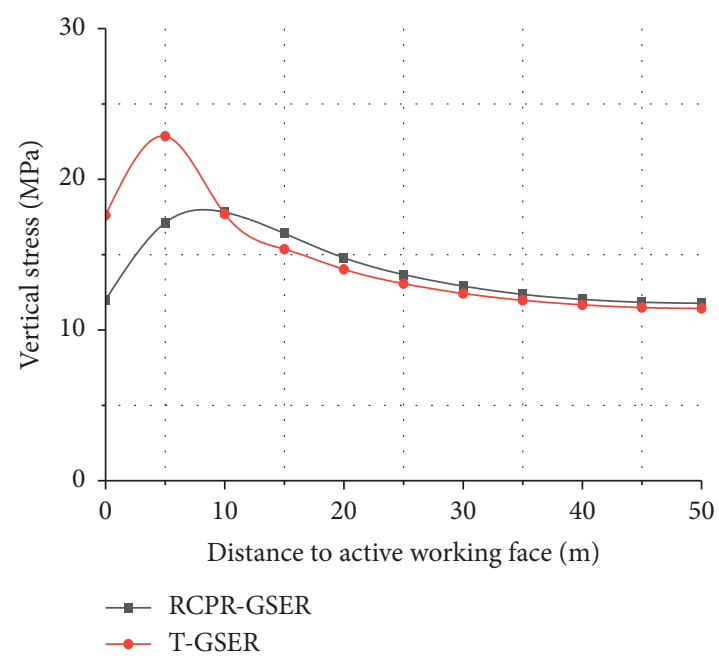

(a)

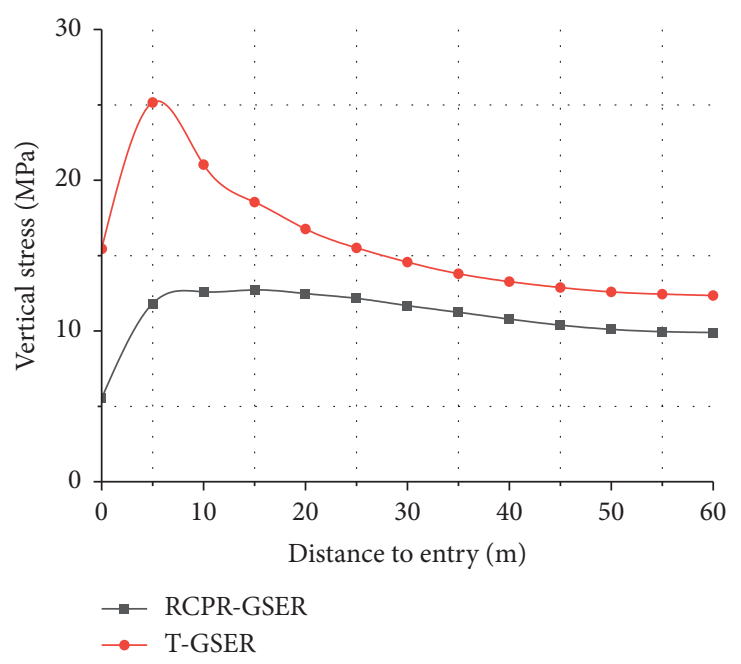

(b)

FIgURE 22: Vertical stress distribution curve of two gob-side entry retaining methods.

deformation of the entry continued to increased, and the velocity of deformation was distinctly reduced. In the third stage (stage III: 200 300 m), the deformation tended to be stable. The final deformation values of the roof subsidence $\left(E-E_{0}\right)$, roof subsidence $\left(P-P_{0}\right)$, floor heave, and entry side displacement were $263 \mathrm{~mm}$, $164 \mathrm{~mm}, 88 \mathrm{~mm}$, and $126 \mathrm{~mm}$, respectively. Compared with stage I of the gob-side entry retained by RCPR, the deformation distance and the maximum deformation rate of gob-side entry retaining by GERF were increased. However, the surrounding rock deformation rules of gob-side entry retaining by different methods were the same and nonharmonious, and the roof subsidence $\left(E-E_{0}\right)>\left(P-P_{0}\right)$.

(3) The support pressure peak near the gob-side entry retained by RCPR is $32.2 \mathrm{MPa}$ with an average peak of $28.8 \mathrm{MPa}$. The support pressure peak near the gobside entry retained by GERF is $38.7 \mathrm{MPa}$ with an average peak of $33.6 \mathrm{MPa}$. The support pressure peak is decreased by $6.5 \mathrm{MPa}$, which is reduced by approximately $16.8 \%$. The average resistance is decreased by $4.8 \mathrm{MPa}$, which is reduced by approximately $14.3 \%$. The monitoring data indicate that roof cutting caused a decrease in the weighting intensity and weakened the support pressure to some extent within a certain range due to gob-side entry retaining by RCPR. The experimental results show that the methods for gob-side entry retaining has a certain influence on the effect of retained entry. When conducting retaining entry, an appropriate method of entry retaining should be selected based on the geology and the requirements of the retaining roadway.

\section{Data Availability}

The data used to support the findings of this study are available from the corresponding author upon request.

\section{Conflicts of Interest}

The authors declare that they have no conflicts of interest.

\section{Authors' Contributions}

Enze Zhen and Yubing Gao contributed equally to this work.

\section{Acknowledgments}

This work was supported by the State Key Laboratory for GeoMechanics and Deep Underground Engineering, China University of Mining and Technology, Beijing (No. SKLGDUEK1928), National Natural Science Foundation of China (No. 51674265), and China Postdoctoral Science Foundation (No. 2019M650896), which are gratefully acknowledged.

\section{References}

[1] Y. Xue, "From tradition to modern times: evolution of coal mining technology in China," Journal of Hubei Polytechnic University (Humanities and Social Science), vol. 30, no. 5, pp. 7-15, 2013.

[2] Y. X. Wu, Views on the Development of Coal Mining Technology in Modern England, Shaanxi Normal University, Xi'an, China, 2011.

[3] M. C. He, Y. B. Gao, J. Yang et al., “An innovative approach for gob-side entry retaining in thick coal seam longwall mining," Energies, vol. 10, no. 12, p. 1785, 2017.

[4] Y. L. Tan, F. H. Yu, J. G. Ning, and T. B. Zhao, "Design and construction of entry retaining wall along a gob side under hard roof stratum," International Journal of Rock Mechanics and Mining Sciences, vol. 77, pp. 115-121, 2015.

[5] D. S. Zhang, L. Q. Ma, G. M. Feng et al., "The technique of gob-side entry retaining with entry-in packing on its original position in fully-mechanized coalface with top-coal caving," Chinese Journal of Rock Mechanics and Engineering, vol. 24, no. 7, pp. 1164-1168, 2005. 
[6] Y. Chen, J. B. Bai, T. L. Zhu et al., "Mechanisms of roadside support in gob-side entry retaining and its application," Rock and Soil Mechanics, vol. 33, no. 5, pp. 1427-1432, 2012.

[7] J. K. Wu, J. G. Kan, S. R. Xie et al., "Failure mechanisms and control of surrounding rock of deep gob-side entry retaining in soft rock strata under high stress," Rock and Soil Mechanics, vol. 33, no. 3, pp. 793-800, 2017.

[8] M. He, G. Zhu, and Z. Guo, "Longwall mining "cutting cantilever beam theory" and 110 mining method in China-the third mining science innovation," Journal of Rock Mechanics and Geotechnical Engineering, vol. 7, no. 5, pp. 483-492, 2015.

[9] G. F. Zhang, M. C. He, X. P. Yu et al., "Research on the technique of no-pillar mining with gob-side entry formed by advanced roof caving in the protective seam in Baijiao coal mine," Journal of Mining and Safety Engineering, vol. 28, no. 4, pp. 511-516, 2011.

[10] Y. Zhang, "Large deformation mechanism of roadway driving along goaf under unstable overlying rock Strata," Journal of Mining \& Safety Engineering, vol. 29, no. 4, p. 451, 2012.

[11] J. W. Zhang, "Study on the surrounding rock structure of stagger layout roadway and its pressure release as well as deformation yielding mechanism," Journal of China Coal Society, vol. 43, no. 8, pp. 2133-2144, 2018.

[12] J. G. Kan, "Structure stability analysis and control technology of surrounding rock of the secondary gob-side entry retaining," Journal of Mining \& Safety Engineering, vol. 35, no. 5 , p. $877,2018$.

[13] M. C. He, "Control of surrounding rock structure for gob-side entry retaining by cutting roof to release pressure and its engineering application," Journal of China University of Mining and Technology, vol. 46, no. 5, p. 959, 2017.

[14] S. R. Xie, "Surrounding rock principal stress difference evolution law and control of gob-side entry driving in deep mine," Journal of Mining \& Safety Engineering, vol. 40, no. 10, pp. 2355-2360, 2015.

[15] J. K. Wu, "Mechanism of asymmetric failure in deep gob-side entry retaining and its control technology," Journal of Mining \& Safety Engineering, vol. 34, no. 4, p. 739, 2017.

[16] Q. Wang, M. He, J. Yang, H. Gao, B. Jiang, and H. Yu, "Study of a no-pillar mining technique with automatically formed gob-side entry retaining for longwall mining in coal mines," International Journal of Rock Mechanics and Mining Sciences, vol. 110, pp. 1-8, 2018.

[17] Y. F. Li, "Mechanical analysis on the stability of surrounding rock structure of gob-side entry retaining," Journal of China Coal Society, vol. 42, no. 9, pp. 2262-2269, 2017.

[18] L. Yuan, "Theory and practice of integrated pillarless coal production and methane extraction in multi-seams of low permeability," Engineering Science, vol. 11, no. 5, pp. 72-80, 2009.

[19] S. L. Lu, "Analysis of the rock behavior and the stress in surrounding rook of the roadway in pillarless mining," Journal of China Coal Society, vol. 18, no. 4, pp. 29-37, 1981.

[20] M. G. Qian, J. L. Xu, and X. X. Miao, "Green technique in coalmining," Journal of China University of Mining Technology, vol. 32, no. 4, pp. 343-347, 2003.

[21] Y. Gao, Z. Guo, J. Yang, J. Wang, and Y. Wang, "Steady analysis of gob-side entry retaining formed by roof fracturing and control techniques by optimizing mine pressure," Journal of China Coal Society, vol. 42, no. 7, pp. 1672-1681, 2017.

[22] M. He, Y. Gao, J. Yang, Z. Guo, E. Wang, and Y. Wang, "The energy-gathered roof cutting technique in non-pillar mining and its impact on stress evolution of surrounding rocks,"
Chinese Journal of Rock Mechanics and Engineering, vol. 36, no. 6, pp. 1314-1325, 2017.

[23] J. Wang, J. Ning, P. Qiu, S. Yang, and H. Shang, "Microseismic monitoring and its precursory parameter of hard roof collapse in longwall faces: a case study," Geomechanics and Engineering, vol. 17, no. 4, pp. 375-383, 2019.

[24] Y. Gao, Y. Wang, J. Yang, X. Zhang, and M. He, "Meso- and macroeffects of roof split blasting on the stability of gateroad surroundings in an innovative nonpillar mining method," Tunnelling and Underground Space Technology, vol. 90, pp. 99-118, 2019.

[25] Z. M. Ma, Z. B. Guo, X. Y. Liu, and H. H. Wang, "Study on bulking rule and mechanical characteristics of fallen gangue in roof-cutting entry retaining," Coal Engineering, vol. 49, no. 11, pp. 94-98, 2017. 


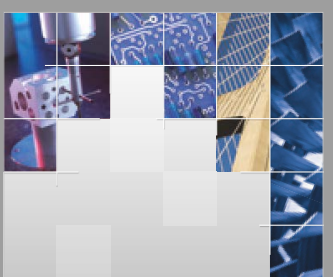

\section{Enfincering}
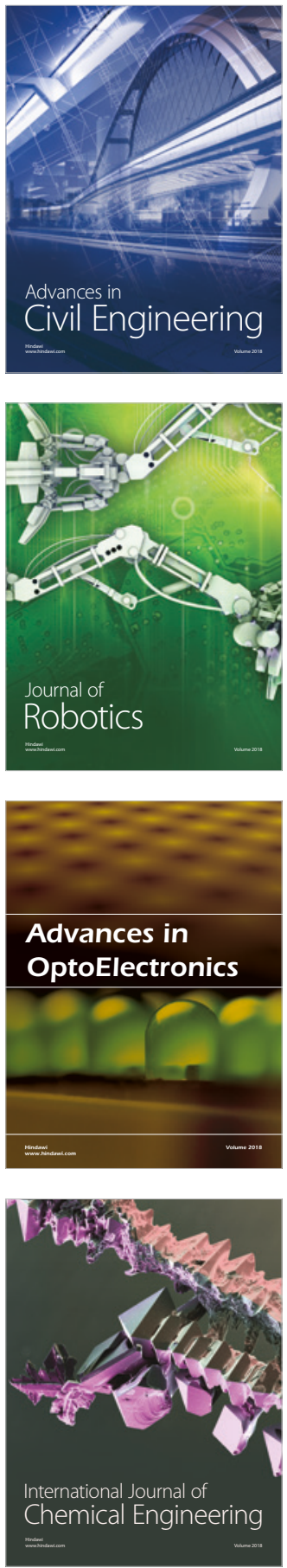

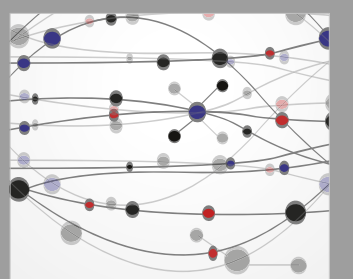

\section{Rotating \\ Machinery}

The Scientific World Journal

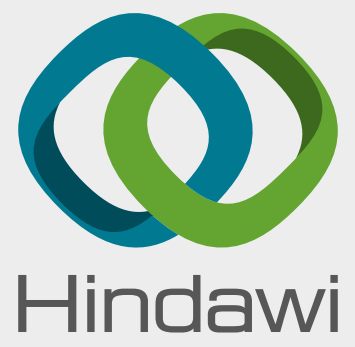

Submit your manuscripts at

www.hindawi.com
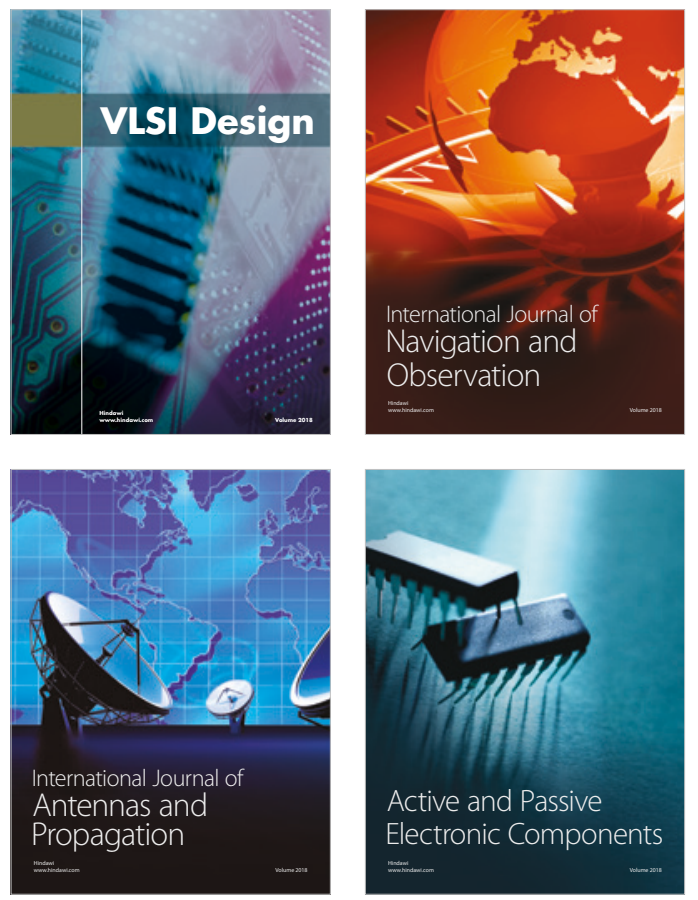
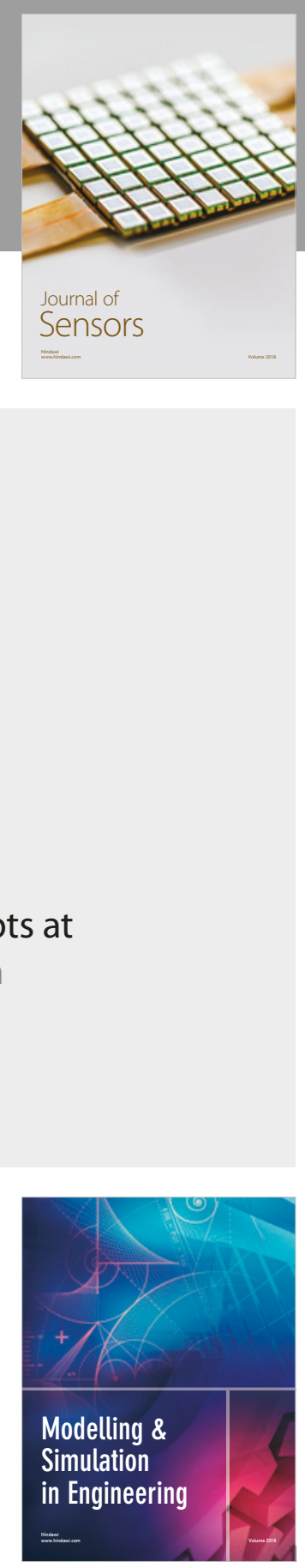

\section{Advances \\ Multimedia}
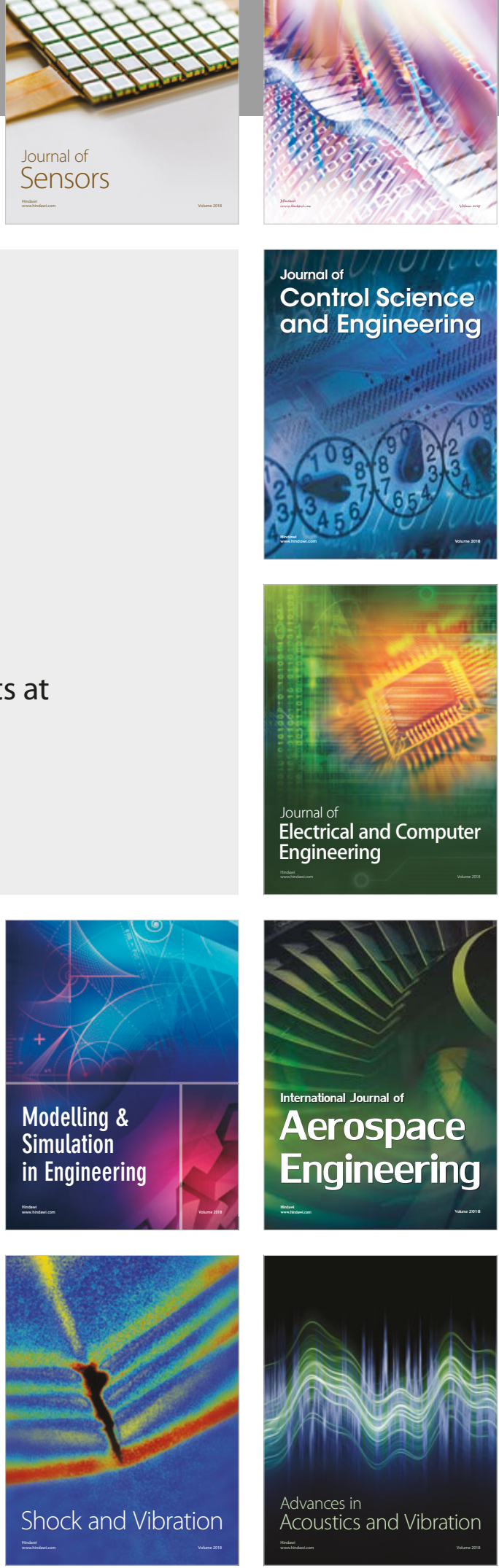